\title{
CREATIVE ACCOUNTING: FROM CREATIVITY TO MISUSE
}

\author{
Rajmund Mirdala ${ }^{1}$, Vule Mizdraković ${ }^{2}$, Nada Arežina ${ }^{2}$, Danka Stefanović ${ }^{2}$ \\ ${ }^{1}$ Faculty of Economics, Technical University, Kosice, Slovak Republic \\ ${ }^{2}$ Faculty of Business in Belgrade, Singidunum University, Belgrade, Serbia
}

\begin{abstract}
:
In this paper we have two goals; the first one is to determine whether there is the clear line between the innovative use of creative accounting techniques and their misuse. The second one is to check whether the accountants are aware of that line and the situations in which they cross it. The implementation of positive and especially negative, creative accounting techniques is expected in economies in growth or in turmoil financial conditions. However, companies' management probably wants to benefit from the use of positive creative accounting techniques, without stepping into its prohibitive use. Therefore, we have conducted a brief survey in the biggest cities of the Republic of Serbia, in order to provide a better insight regarding accountant's opinions whether that line exists in practice.
\end{abstract}

\author{
Key words: \\ positive and negative creative ac- \\ counting, \\ prohibitive use, \\ accountants, \\ Serbia.
}

\section{INTRODUCTION}

Financial reporting provides the recordings of business transactions related to certain business entity. Different stakeholders use accounting information as an input in the decision-making process. Since both external and internal users of financial reports have their different decisions based on information presented in the financial statements, they should truthfully present the financial condition of a given business entity. If financial reporting system is organized in a proper way, which means that the financial statements have been prepared in compliance with professional legislation, as well as in compliance with the relevant principles and methods, the financial statement users should make the right business decisions. However, due to different goals and intentions of the persons who prepare financial statements, that image may be distorted because of the various manipulations and illegal actions which make the financial position and profitability of business entity better than they truly were. In this manner, the management uses the aforementioned as a tool for achieving different objectives; regardless of whether they intent to increase or decrease financial results. Meanwhile, the very important question remains: Do the accountants know where are the boundaries between the positive and negative creative accounting? Consequently, we wonder do they know where the fine line is between permitted and prohibited use of accounting methods and techniques. This paper will be structured as follows: the first part of the article explains what creative accounting is and what techniques and methods it includes. The second part of the paper refers to research methodology and presents the research results, as well.

\section{THE POSITIVE AND NEGATIVE CREATIVE ACCOUNTING CONCEPTS}

The term creative accounting has its two sides: positive and negative; depending on whether the methods used fall outside the current financial reporting regulations, or not. Nevertheless, this term in practice has usually negative connotation and is also named "tax smoothing", "income smoothing", "cosmetic" accounting and "financial engineering" [1]. The term "creative" is used to indicate the opposite of "consistent" and "conservative" in accounting principles, which is commonly used as a kind of cynical remark to managers who secretly decorate the financial statements [2]. Consequently, considering that creative accounting does not necessarily imply the breach of legal regulations and professional legislation, it can be said that there is "white" and "black", or positive and negative creative accounting [1]. However, sometimes it is difficult to clearly distinct when aggressive accounting turns into illegal. As Gerboth states, rationality and objectivity of accounting are based on the level of rationality and objectivity of the person who interprets the rules [3]. Still, creative accounting can turn into criminal activity and this type of creative accounting usually gets all of the attention, given the damage it causes on financial statement users.

If we take into account the previously mentioned definition, it can be said that creative accounting refers to the process of implementation of accounting procedures and methods, which requires solid accounting knowledge. Aforementioned is used to manipulate balance sheet positions and their values. If there is a violation of laws and professional legislation during that process, then creative accounting can turn into a fraudulent and illegal financial reporting. Therefore, some authors, as stated by Malinic (2009), suggests that creative accounting (black and white) derogates the use of financial statements information, whether in terms of direct use of the information therein, or as a basis for financial statements analysis of certain business entity [4]. Crumbley and Apostolou (2001) suggest that investors when assessing the quality, reliability and integrity of financial information, must "examine" the financial statements and the disclosed information, the way Sherlock Holmes approaches the murder cases [5].

A number of accounting scandals speak in favor of the claim that the management was often involved in the manipulation of financial statements to reflect the poorer business results, due to tax evasions. The other goal is to show a better result than achieved in order to attain bonuses, or the assets overvaluation, which could result in unjustified loan granting by financial institutions [6].

Although the change of International Financial Reporting Standards (IFRS) reduced the possibility of information misuse, they still cannot completely eliminate the risk of financial statements manipulation. Diversity of business and its everyday development made accounting flexible regarding the application of different assessments, which open the possibilities for 
different types of financial statements manipulations. According to the Belak (2011) there are three areas of creative accounting implementation that fall within financial reporting legislation [7]. The first area is situation where legislation does not allow alternative methods of valuation or recognition; hence there is no flexibility in its implementation. The second area is increased flexibility of financial reporting legislation, where the creative accounting users can achieve their goals and retain the fairness and truthfulness of financial reporting. The third area is on the verge of illegal financial reporting, as it considers implementation of creative accounting techniques that result in better presentation of the financial condition and profitability of a certain entity. According to the aforementioned author, the flexibility of financial reporting that leads to the fraudulent financial reporting is the creative accounting implementation that falls beyond the financial reporting legislative frame.

It can be said that there is a fine line between the use of positive creative accounting methods and actions that resembles the fraud, as defined by International Standards on Auditing: An intentional act by one or more individuals among management, those charged with governance, employees, or third parties, involving the use of deception to obtain an unjust or illegal advantage [8]. This category includes illegality intentional misstatements of certain financial values that would strengthen the illusion of profitability and mislead shareholders and creditors [9].

\section{RESEARCH METHODOLOGY AND RESULTS}

In order to find out what is the attitude of professional accountants in Serbia towards creative accounting, we conducted a brief survey. The research had been conducted in the period from August to mid-October, 2014. The primary method of data collection was an anonymous survey with general questions and those related to the creative accounting use. The research involves the collection of primary data that are considered more relevant, compared to the data collected from already conducted researches. Questionnaires were distributed to accountants who are either employed in bookkeeping agencies or do financial reporting in different legal entities. Several respondents are even owners of bookkeeping agencies. The survey was distributed in the territory of the largest cities in the Republic of Serbia: Belgrade, Novi Sad, Nis and Valjevo. Out of total questionnaires sent to 259 e-mail addresses, we have received 38 completed surveys. However, four surveys (out of 38) were not included in the analysis results, because the respondents gave incomplete answers to the questions, therefore, these responses did not seem relevant to the research and were excluded. Therefore, there were 34 properly filled questionnaires, which makes response rate of $13.1 \%$ of the total sample. The above response rate is considered to be solid for this type of questionnaire, and yet there is a high probability that the results of the study would be completely different if the response rate was higher. Therefore, all the conclusions that we derive in this paper should be used with great caution and more as guidelines, not as rules, bearing in mind that a large number of accountants did not want to answer the survey. On the other hand, submitted questionnaires give the impression of honest replies and opinions. The software solution SPSS (Statistical Package for the Social Sciences) as a statistical program for data processing has been used as an instrument of data processing.

On the pages that follow, we have presented the results of our research. We were interested in finding out what is the point of view of accountants in the Republic of Serbia regarding the creative accounting use. We wanted to know what their first thought is regarding to the creative accounting implementation, as well as whether it has negative or positive implication in their minds. The results are presented in the figure number 1 .

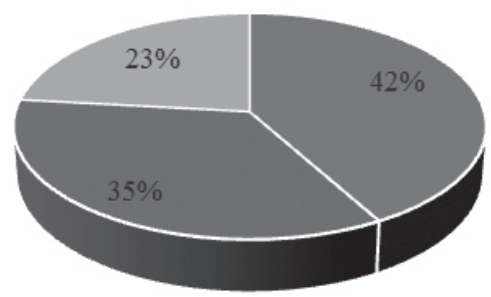

- Conforms to the financial reporting legislation

- Does not conform to the financial repoting legislation

- Not sure

Figure 1. Does creative accounting consider implementation of accounting methods that fall within the financial reporting legislation or not?

It is interesting to notice that almost half of the respondents consider creative accounting as the process of implementation of accounting techniques that fall within the financial reporting legislative frame. Nevertheless, one quarter or the respondents do not have clear thoughts on this problem, which could be contemplated as a proof that the line between positive and negative creative accounting is indeed very thin.

Having in mind aforementioned goals that creative accounting implementation could achieve, the management of the entity will probably be interested in its application. Therefore, we were interested in finding out do the accountants feel the pressure of creative accounting use, especially its negative side. The results are presented in the figure number 2 .

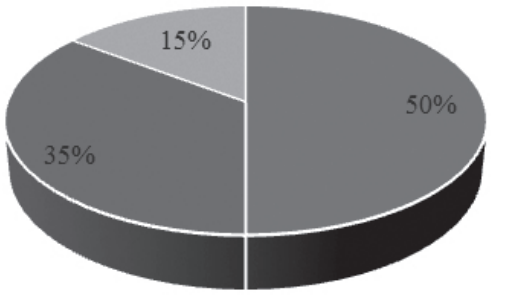

- Uses positive creative accounting techniques

- Uses negative creative accounting techniques

- Not sure

\begin{abstract}
Figure 2. Does management consider "good" accountant the one that uses positive or negative creative accounting techniques?
\end{abstract}

It seems that accountants do feel the pressure to use creative accounting techniques. Still, they do think that creative accounting could be used without breaching financial reporting legislation and retaining the integrity of this profession, at the same time. Finally, in order to gain a better comprehension of increased use of both positive and negative creative accounting implementation, we have asked the accountants what is the importance of several factors that lead to its increased use. The results are presented in the figure number 3.

Analysis of the results using one-way ANOVA, where the independent variable related to the opinion whether the accountants believe that creative accounting conforms to the financial reporting legislative frame or not and the dependent variable related to the significance of the factors that contributes to the increased use of creative accounting (as presented on the figure above) led to the certain results.

Results show that the level of the importance of lack of regulation or incomprehensiveness of IFRSs statistically differs depending on the comprehension of creative accounting as 


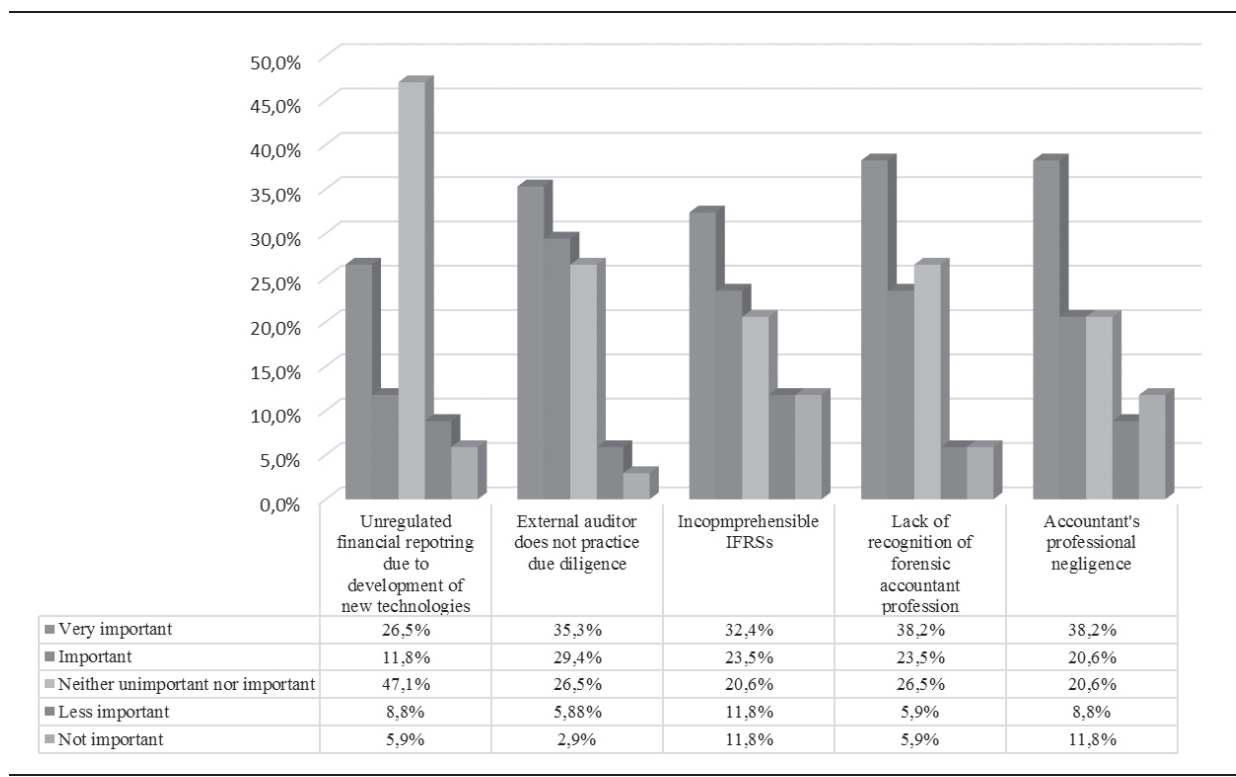

Figure 3. The most important factors of increased creative accounting implementation

able to differentiate it. A significant number of accountants consider that the use of positive creative accounting techniques is necessary if they want to be considered as the "good" accountants by the management of the companies. The authors believe that it would be necessary to pay attention to the further education of professional accountants and their professional development in the future, as well as to promote the forensic accounting and auditing profession in order to achieve that creative accounting techniques will not be misused.

\section{REFERENCES}

[1] G. Knezevic, N. Stanisic, V. Mizdrakovic, Analiza finansijskih izvestaja, $1^{\text {st }}$ ed., Serbia, Singidunum University, 2013.

either positive or negative, $\mathrm{F}(2,31)=3.359$, ( $\mathrm{p}<.05)$. Namely, the respondents who think that creative accounting conforms to the professional legislation, consider this factor important $(\mathrm{M}=3.94)$. While respondents who believe that creative accounting does not conform to the professional legislation are indifferent to this factor $(M=3.2)$. Aforementioned could be comprehended in the way that accountants who consider creative accounting as a positive, do not believe that the reason for its use is the pressure of management to achieve the desired goals, but the flexibility of professional legislation for its use. Therefore, they consider creative accounting as a positive. On the other hand, accountants who consider creative accounting as negative believe that the incomprehensiveness of IFRSs does not have a significant impact on the use of creative accounting. They probably believe that the intentions of management to achieve their goals lead to the use of accounting techniques that surpass professional regulatory frame.

\section{CONCLUDING REMARKS}

The research results of this study show that professional accountants in Serbia believe that creative accounting techniques conform to the financial reporting legislation, but it is important to emphasize that a significant number of accountants are not able to distinguish the positive creative accounting from the negative one. Aforementioned suggests that there is a fine line between these two terms and sometimes accountants are not

[2] H. Ling-Feng, T. Yao-Tsung, Information Asymmetry, Creative Accountings and Moral Choice: An Apocalypse of Procomp Informatics Ltd., Journal of American Academy of Business, vol. 6, no. 2, 2005, pp. 64-73.

[3] D. Gerboth, The Conceptual Framework: Not Definitions, but Professional Values, Accounting Horizons, vol. 1, no. 3, 1987, pp. 1-8.

[4] D. Malinic, Savremeni izazovi integralnog istrazivanja kvaliteta finansijskih izvestaja, Ekonomika preduzeca, vol. 57, no. 1, 2009, pp. 138-155.

[5] L. Crumbley, N. Apostolu, N, Cook the books and you will go directly to jail, Journal of Forensic Accounting, vol. 2, no. 1, 2001, pp. 131-138.

[6] G. Knezevic, V. Mizdrakovic, N. Arezina, Management as cause and instrument of creative accounting suppression. Management - časopis za teoriju i praksu menadžmenta, vol. 17, no. 62, 2012, pp. 5-11.

[7] V. Belak, Poslovna forenzika i forenzičko računovodstvo Borba protiv prijevare, Croatia, Zagreb, Belak Ecxellencs, 2011.

[8] Z. Petrovic, Racunovodstvena regulativa, Serbia, Belgrade, Singidunum University, 2008.

[9] J. Bologna, R. Lindquist, Fraud Auditing and Forensic Accounting. USA, New York, John Wiley and Soons, 1995.

\section{KREATIVNO RAČUNOVODSTVO - OD KREATIVNOSTI DO ZLOUPOTREBE}

Rajmund Mirdala ${ }^{1}$, Vule Mizdraković ${ }^{2}$, Nada Arežina ${ }^{3}$, Danka Stefanović ${ }^{4}$

${ }^{1}$ Faculty of Economics, Technical University, Němcovej 32, Kosice, Slovak Republic, rajmund.mirdala@tuke.sk

${ }^{2}$ Poslovni fakultet u Beogradu, Univerzitet Singidunum, Danijelova 32, Beograd, Srbija, vmizdrakovic@singidunum.ac.rs

${ }^{3}$ Poslovni fakultet u Beogradu, Univerzitet Singidunum, Danijelova 32, Beograd, Srbija, narezina@singidunum.ac.rs

${ }^{4}$ Poslovni fakultet u Beogradu, Univerzitet Singidunum, Danijelova 32, Beograd, Srbija, dstefanovic@singidunum.ac.rs

\begin{abstract}
Apstrakt:
Postoje dva osnovna cilja ovog rada, prvi jeste pokušaj da proverimo da li postoji jasna granica između kreativne upotrebe računovodstvenih tehnika i njihove zloupotrebe. Drugi cilj je provera u kojoj meri su računovođe shvataju da ta granica postoji i kada je oni u praksi prelaze. Upotreba pozitivnih, a naročito negativnih tehnika kreativnog računovodstva, očekivana je u privredama u razvoju ili u nepovoljnim finasijskim uslovima poslovanja. Međutim, uprave pravnih lica verovatno žele da ispune određene ciljeve upotrebom tehnika pozitivnog kreativnog računovodstva, a da pritom ne pređu granicu njihovog nezakonitog korišćenja. Stoga, u ovom radu smo sproveli kratko istraživanje u najvećim gradovima Republike Srbije, koje je uključivalo anketiranje računovođa, kako bismo obezbedili bolji uvid u razumevanje ove problematike.
\end{abstract}

\section{Ključne reči:}

pozitivno i negativno kreativno računovodstvo, nezakonita upotreba, računovođe, Srbija. 